\title{
Phenotypic and Genotypic Diversity of Pseudomonas tolaasii and White Line Reacting Organisms Isolated from Cultivated Mushrooms
}

\author{
By M. GOOR, ${ }^{1 *}$ R. VANTOMME, ${ }^{2}$ J. SWINGS, ${ }^{1}$ M. GILLIS, ${ }^{1}$ \\ K. KERSTERS ${ }^{1}$ AND J. DE LEY ${ }^{1}$ \\ Laboratorium voor Microbiologie en Microbiële Genetica, Rijksuniversiteit Gent ${ }^{1}$ \\ and Onderzoekscentrum voor Fytobacteriosen, Sektie II, IWONL ${ }^{2}$, Ledeganckstraat 35, \\ B-9000 Gent, Belgium
}

(Received 11 September 1985; revised 28 February 1986)

\begin{abstract}
We compared 21 bacterial strains isolated in Belgium from cultivated Agaricus bisporus, Pleurotus ostreatus and Psalliota edulis showing typical brown blotch symptoms, with 12 culture collection strains of Pseudomonas tolaasii, nine $P$. agarici strains causing drippy gill, four ' $P$. gingeri' strains causing ginger blotch, three Pseudomonas strains responsible for mummy disease, three saprophytic $P$. fluorescens, four $P$. aeruginosa and three ' $P$. reactans' strains. All strains were characterized by 147 auxanographic API tests (API 50CH, API 50AO, API 50AA) and by 128 (for 14 strains, 55) additional biochemical, serological and phytopathological features. The results were analysed by numerical methods. Taking into account also results obtained by gel electrophoresis of soluble proteins and by DNA:DNA hybridizations, we were able to differentiate seven groups, corresponding respectively to $P$. aeruginosa (phenon $\mathrm{I}$ ), $P$. fluorescens biovar II (phenon II), 'P. gingeri' (phenon III), $P$. tolaasii, including nine of our own isolates (phenon IV), the so-called white line reacting organisms, containing 11 of our own isolates (phenon V), two mummy disease isolates (phenon VI) and P. agarici (phenon VII). P. tolaasii formed a homogeneous group, containing both virulent and avirulent strains. The saprophytic white line reacting organisms of phenon $V$ were, despite their phenotypic similarity, heterogeneous genotypically and in their gel electrophoresis patterns. A determinative scheme for the differentiation of $P$. tolaasii, the white line reacting organisms and the other Pseudomonas species occurring on mushrooms is proposed.
\end{abstract}

\section{INTRODUCTION}

Brown blotch disease (Tolaas, 1915), the most serious and commonly spread disease on cultivated mushrooms, is caused by Pseudomonas tolaasii (Paine, 1919). The appearance of sunken chocolate-brown lesions on the caps and stipes of affected mushrooms is responsible for considerable quality losses. As much as $7-10 \%$ of the total Belgian mushroom production may be lost due to this disease. Three other members of the genus Pseudomonas induce diseases on cultivated mushrooms: $P$. agarici, causing drippy gill (Young, 1970); 'P. gingeri', causing ginger blotch (Wong et al., 1982) and an unidentified Pseudomonas species responsible for mummy disease (Schisler et al., 1968). Moreover, the occurrence of many saprophytic pseudomonads has been reported frequently on mushrooms and in their environment (Olivier et al., 1978; Zarkower et al., 1984). Some of these saprophytic Pseudomonas were capable of inducing a 'white line reaction' with $P$. tolaasii and were designated as 'reacting organisms' (Wong \& Preece, 1979) or 'inducers' (I strains) (Zarkower et al., 1984). Few authors have discussed the taxonomic position of Pseudomonas strains associated with mushrooms. From the existing literature (Young, 1970; Fahy, 1981), the differentiation of P. tolaasii and P. agarici was possible, whereas differentiation between the other pseudomonads associated with mushrooms posed more problems. According to Fahy (1981) P. tolaasii comprised both saprophytic and pathogenic isolates whereas other 
authors (Wong \& Preece, 1979; Zarkower et al., 1984) stated that the white line reacting organisms were clearly distinct from $P$. tolaasii. Zarkower et al. (1984) advocated the use of the white line test as a diagnostic tool for the identification of $P$. tolaasii.

In this study we concentrated on $P$. tolaasii and on the white line reacting organisms. Our aims were as follows: (i) to characterize 46 culture collection strains of Pseudomonas isolated mostly from cultivated mushrooms, using 275 auxanographic and other phenotypic tests; (ii) to identify 21 strains isolated in Belgium from cultivated mushrooms with brown blotch symptoms by comparing their phenotypic features with those of the culture collection strains; (iii) to determine the diversity within $P$. tolaasii and the white line reacting organisms by numerical analysis of phenotypic features and by comparing their soluble protein gel electrophoretic patterns; (iv) to determine the genotypic relationships of $P$. tolaasii and the white line reacting organisms by DNA : DNA hybridizations; and (v) to select diagnostic features for a simple and accurate identification of $P$. tolaasii and the other Pseudomonas species associated with cultivated mushrooms.

\section{METHODS}

Bacterial strains, media and inocula. Samples from the mushroom species Agaricus bisporus, Psalliota edulis and Pleurotus ostreatus showing typical brown blotch lesions were collected in different farms in Belgium. The blotched outer tissue layers were suspended in sterile physiological saline $(0.85 \% \mathrm{NaCl})$. Two drops of each suspension were plated on Pseudomonas agar F (PAF) containing $1 \%(\mathrm{w} / \mathrm{v})$ tryptone, $1 \%(\mathrm{w} / \mathrm{v})$ proteose peptone, $1 \%(\mathrm{w} / \mathrm{v})$ glycerol, $0.15 \%(\mathrm{w} / \mathrm{v}) \mathrm{MgSO}_{4}, 0.15 \%(\mathrm{w} / \mathrm{v}) \mathrm{K}_{2} \mathrm{HPO}_{4}$ and $2.5 \%(\mathrm{w} / \mathrm{v})$ agar. Single fluorescent colonies were selected and streaked to obtain pure cultures. Different colony forms appearing after subculturing were labelled $\mathrm{tl}, \mathrm{t} 2, \mathrm{t} 3$. Twenty-one isolates, together with 46 culture collection strains, were included in this study (Table 1). Type strains are denoted by a superscript $T$. The legend to Table 1 explains the use of single and double inverted commas for certain names. Inoculation of all liquid media was performed with two drops of a bacterial suspension containing about $10^{9}$ cells per ml physiological saline and made from a 24-48 h-old starter culture on PAF slants. Unless otherwise stated, all tests were incubated at $28^{\circ} \mathrm{C}$.

Pathogenicity tests. The method of Olivier et al. (1978) was applied on the mushroom variety Agaricus bisporus Somycel 53. Two drops of a bacterial suspension containing approximately $10^{9}$ cells per $\mathrm{ml}$ sterile distilled water were applied to each mushroom cap. Controls were made with sterile water. Each bacterial culture was tested at least twice. Results were read after 1 and $2 \mathrm{~d}$ incubation at $23^{\circ} \mathrm{C}$. Inoculations were also performed on mushroom beds in farming conditions.

White line test. This was done on all strains according to Wong \& Preece (1979). In PAF medium a characteristic white precipitation band between opaque white colonies of authentic $P$. tolaasii strains and translucent colonies of the so-called white line reacting organisms was formed. Wong \& Preece (1979) recommended this test as a reliable method to monitor $P$. tolaasii strains in mushroom crops. In our study, strain NCPPB 1311 was used to detect $P$. tolaasii, whereas $P$. tolaasii $\mathrm{NCPPB} 2192^{\mathrm{T}}$ was also used to select the white line reacting organisms. The formation of a white line was followed during $6 \mathrm{~d}$ at $23^{\circ} \mathrm{C}$.

Serology. The antiserum (24l/1) used for slide agglutinations was prepared at the Unite de Phytopathologie, Centre d'Études des Phytobactérioses (Section I), Université Catholique de Louvain-la-Neuve, Belgium, against the type strain of $P$. tolaasii NCPPB $2192^{\mathrm{T}}$. A bacterial suspension $(0.5 \mathrm{ml})$ containing approximately $10^{9}$ cells $\mathrm{ml}^{-1}$ was treated with formalin according to Laroche \& Verhoyen (1981) and injected intravenously into a rabbit twice in $4 \mathrm{~d}$. Blood was collected $4 \mathrm{~d}$ after the last injection. The titre of the antiserum reached $1 / 320$ using the agglutination test against whole cells.

API systems. In the auxanographic API systems (API System, France) growth tests were done on 49 sugars and derivatives (50CH), 49 organic acids (50AO) and 49 amino acids and amines (50AA) (see Tables 2 and 3). Strains were grown on nutrient agar slants containing $0.01 \mathrm{M}$-phosphate buffer $\left(\mathrm{pH} \mathrm{6.8)}\right.$ for $48 \mathrm{~h}$ at $28^{\circ} \mathrm{C}$. The basal medium for the carbon assimilation tests was prepared by the addition of $5 \mathrm{ml}$ of a filter-sterilized solution of $8.04 \%(\mathrm{w} / \mathrm{v})$ Yeast Nitrogen Base (Difco) and $0.6 \%(\mathrm{w} / \mathrm{v})$ Yeast Extract Powder (Oxoid) to $55 \mathrm{ml}$ sterilized $0.1 \mathrm{M}$ phosphate buffer ( $\mathrm{pH} 7 \cdot 0$ ) containing $0.2 \mathrm{~g}$ Oxoid agar no. 1 . The medium was mixed and held in a $43^{\circ} \mathrm{C}$ water bath. A loopful of bacteria was taken from the slant and suspended in $0.01 \mathrm{M}$-phosphate buffer (pH 7.0). A $3 \mathrm{ml}$ portion of this cell suspension containing approximately $1.5 \times 10^{9} \mathrm{cells} \mathrm{ml}^{-1}$ was added to the basal medium. The test strips were inoculated as indicated by the manufacturer. The final concentration of the substrates was $0.2 \%$ carbohydrates or organic acids, and $0.1 \%$ amino acids or amines. Growth was observed after $1,2,4$ and $7 \mathrm{~d}$. The production of a diffusible fluorescent pigment was noted after 4 and $7 \mathrm{~d}$.

Other morphological, biochemical and physiological tests. Gram reaction, cell morphology and motility were 
observed on cells not older than $24 \mathrm{~h}$. Colony morphology was observed after $2 \mathrm{~d}$ on YPGA $(0 \cdot 5 \%$ yeast extract, $0.5 \%$ peptone, $1 \%$ glucose and $2 \%$ agar; $\mathrm{pH} 7 \cdot 2$ ). Oxidase activity was tested by the method of Kovács (1956). Catalase activity was determined by mixing a loopful of bacteria in a drop of $10 \%(v / v) \mathrm{H}_{2} \mathrm{O}_{2}$. Pigment production was observed on the media of King et al. (1954). Temperature sensitivity was checked in nutrient broth, incubated in water baths at $33,37,39$ and $41^{\circ} \mathrm{C}\left( \pm 0 \cdot 2^{\circ} \mathrm{C}\right)$. Nitrate reduction was tested after $2 \mathrm{~d}$ in nutrient broth containing $0 \cdot 1 \% \mathrm{KNO}_{3}$. Salt tolerance was tested in nutrient broth containing 3, 4, 5, 6 and $7 \%(\mathrm{w} / \mathrm{v}) \mathrm{NaCl}$. Resistance to 23 antibiotics was test:d on YPGA medium according to Bauer et al. (1966), using the following discs (Oxoid): $30 \mu \mathrm{g}$ nalidixic acid, $10 \mathrm{U}$ penicillin $\mathrm{G}, 10 \mu \mathrm{g}$ erythromycin, $10 \mu \mathrm{g}$ ampicillin, $10 \mu \mathrm{g}$ streptomycin, $10 \mu \mathrm{g}$ gentamicin, $2 \mu \mathrm{g}$ lincomycin, $30 \mu \mathrm{g}$ chloramphenicol, $200 \mu \mathrm{g}$ nitrofurantoin, $30 \mu \mathrm{g}$ novobiocin, $10 \mu \mathrm{g}$ fusidic acid, $10 \mathrm{U}$ bacitracin, $10 \mu \mathrm{g}$ methicillin, $10 \mu \mathrm{g}$ colistin sulphate, $30 \mu \mathrm{g}$ tetracycline, $100 \mu \mathrm{g}$ sulphafurazole, $25 \mu \mathrm{g}$ cephaloridine, $30 \mu \mathrm{g}$ neomycin, $300 \mathrm{U}$ polymyxin $\mathrm{B}, 30 \mu \mathrm{g}$ kanamycin, $25 \mu \mathrm{g}$ mecillinam, $30 \mu \mathrm{g}$ cephradine, $10 \mu \mathrm{g}$ tobramycin.

The following additional tests were done on 53 strains (see Table 1). Alkalinization of 14 organic acids was tested in a medium consisting of $0.5 \% \mathrm{NaCl}, 0.02 \% \mathrm{MgSO}_{4} .7 \mathrm{H}_{2} \mathrm{O}, 0.1 \% \mathrm{NH}_{4} \mathrm{H}_{2} \mathrm{PO}_{4}, 0.1 \% \mathrm{~K}_{2} \mathrm{HPO}_{4}, 0.0025 \%$ bromothymol blue and $0.2 \%$ of the filter-sterilized sodium salt of the following organic acids: DL-tartrate, Dgalacturonate, propionate, fumarate, succinate, DL-malate, DL-lactate, D-gluconate, acetate, benzoate, formate, citrate, oxalate, malonate. Glucose utilization was determined according to Hugh \& Leifson (1953). Acid production from 22 carbon sources was tested in the same medium without agar. The following carbohydrates and related compounds were added aseptically to a final concentration of $1 \%(w / v): D$-arabinose, raffinose, starch, dextrin, salicin, dulcitol, $\alpha$-D-melezitose, L-rhamnose, D-lactose, sucrose, D-maltose, D-trehalose, D-fructose, melibiose, inulin, adonitol, meso-inositol, D-xylose, D-glucose, D-ribose, D-mannose, D-mannitol. D-Lactose, raffinose, soluble starch, inulin, dextrin, meso-inositol, salicin and dulcitol were sterilized separately by autoclaving for $10 \mathrm{~min}$ at $120^{\circ} \mathrm{C}$; the other compounds were filter-sterilized. The test was read after 1,2 and $7 \mathrm{~d}$. Gelatin liquefaction was followed for 3 weeks in nutrient broth tubes containing a charcoal gelatin disc (Oxoid). Hydrolysis of casein was followed for $7 \mathrm{~d}$ on nutrient agar with $10 \%(\mathrm{w} / \mathrm{v})$ skim milk powder. The methods of Møller (1955) were used to determine L-arginine dihydrolase and L-lysine- and L-ornithine hydrochloride decarboxylase activities. Production of levan was followed according to Lelliott et al. (1966). $\beta$-Galactosidase activity was checked as described by MacFaddin (1976, method 2). Starch hydrolysis was tested after 1 week on nutrient agar plates containing $0.8 \%$ soluble starch. Lipase activity was tested according to Sierra (1957), using Tween 60 and Tween 80 . Indole, $\mathrm{H}_{2} \mathrm{~S}$ and acetoin production and the formation of reducing substances from sucrose were determined as described by Dye (1968). DNAase activity was followed on Oxoid DNase agar medium (code CM321). After $7 \mathrm{~d}$ incubation, $1 \mathrm{M}-\mathrm{HCl}$ was used to precipitate the non-hydrolysed DNA. Acidification, alkalinization, reduction, coagulation and peptonization in litmus milk were followed for $14 \mathrm{~d}$ in $10 \%$ skim milk powder in distilled water to which $0.06 \%$ soluble litmus was added ( $\mathrm{pH} 6.5)$. The hydrolysis of aesculin was followed during 1 week according to the method of Sneath (1956). Growth factor requirements were determined after 1 week in a medium consisting of $0.01 \% \mathrm{NaCl}, 0.001 \% \mathrm{FeCl}_{3}, 0.05 \%\left(\mathrm{NH}_{4}\right)_{2} \mathrm{HPO}_{4}, 0.1 \%$ glucose with or without $0.3 \%$ yeast extract. Sensitivity towards different chemical compounds $[0.01 \%$ sodium nitrite, $0.01 \%$ potassium nitrite, $0.01 \%$ and $0.2 \%$ hexamethylenetetramine, $0.01 \%$ streptomycin sulphate, $0.01 \%$ kasugamycin technical (60\% pure), 0.01\% CGA 78039 WP50, 0.01\% CGA 78039 ammonium salt, $0.2 \%$ propyl gallate, $0.01 \%$ formaldehyde (35\% pure), $0.2 \%$-hydroxyethylbenzoate sodium salt, $0.2 \%$ sodium benzoate and $0.2 \%$ quinine sulphate] was investigated on YPGA medium. Growth was followed for 2 weeks.

Numerical analysis. Each feature was considered as a separate unit character. Pigmentation and colony morphology were coded, in two or more exclusive states. Codes from 1 (negative) to 7 (strongly positive after $1 \mathrm{~d}$ incubation) corresponding to rate and strength of growth were attributed to the auxanographic features. Other characters were coded as $1(-), 4( \pm)$ and $7(+)$. Missing tests were coded as 0 (zero). The similarity coefficient, derived from the Canberra-metric dissimilarity coefficient, was calculated with an adapted version of the computer program of Bonham-Carter (1967). Strains were clustered using the unweighted average pair-group method (UPGMA) (Sneath \& Sokal, 1973) with the Clustan IC program of Wishart (1978) on the Siemens 7541 (BS 2000) computer of the Centraal Digitaal Rekencentrum of the Rijksuniversiteit Gent.

Polyacrylamide gel electrophoresis of soluble cell proteins. Cells were grown in Roux flasks for $48 \mathrm{~h}$ on nutrient agar. The preparation of cell free extracts, polyacrylamide gel electrophoresis and photography of the stained gels were as described by Kersters \& De Ley (1975). Each protein extract was run at least in duplicate. For some strains the entire procedure was repeated.

DNA : DNA hybridizations. Cells were grown in Roux flasks on nutrient agar or PAF medium for $48 \mathrm{~h}$ and harvested and washed in $0.01 \mathrm{M}$-phosphate buffer $\left(\mathrm{pH} \mathrm{7.0)}\right.$. High $M_{\mathrm{r}}$ DNA was prepared by the method of Marmur (1961) and stored in $0.1 \times \mathrm{SSC}$ at $-80^{\circ} \mathrm{C}$ (SSC is $0.15 \mathrm{M}-\mathrm{NaCl}, 0.015 \mathrm{M}$-trisodium citrate, $\mathrm{pH} 7 \cdot 0$ ). The degree of genome similarity (expressed as $\% D$, degree of duplexing) was determined from the initial renaturation rate (De Ley et al., 1970). Each hybridization experiment was done at least in triplicate. 


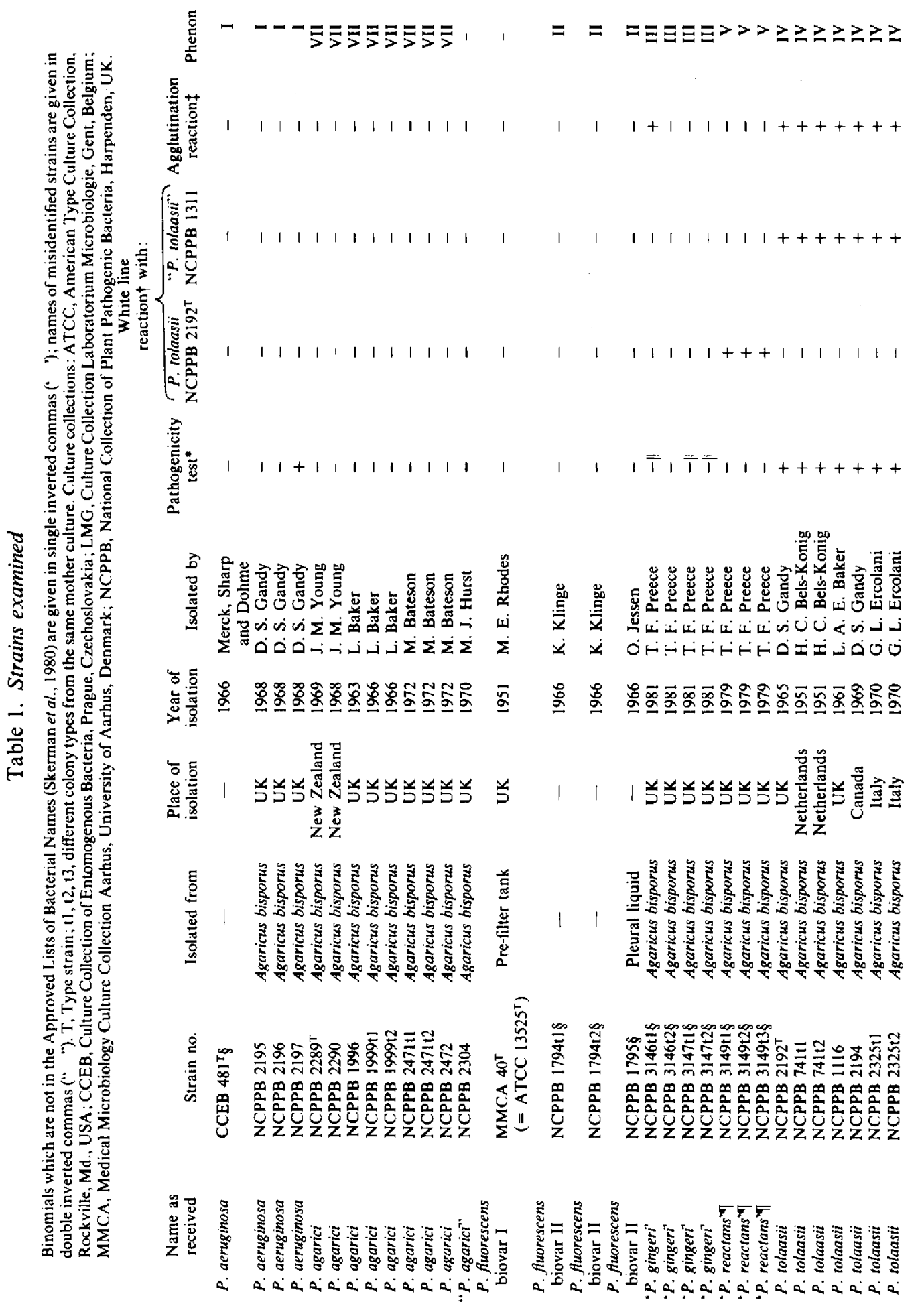



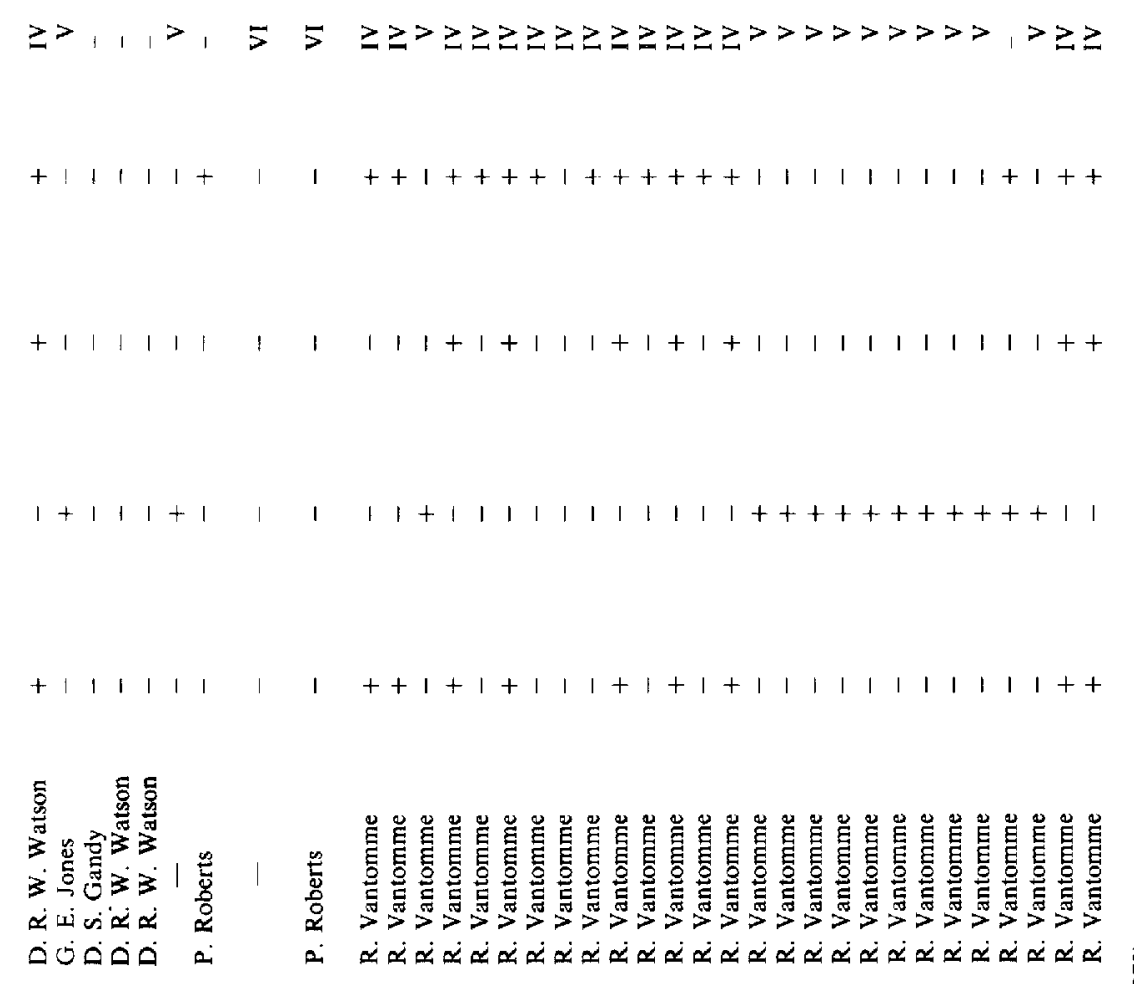

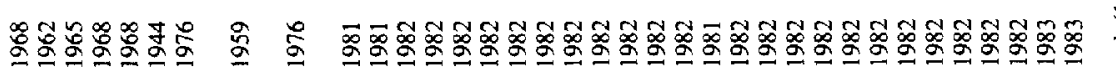

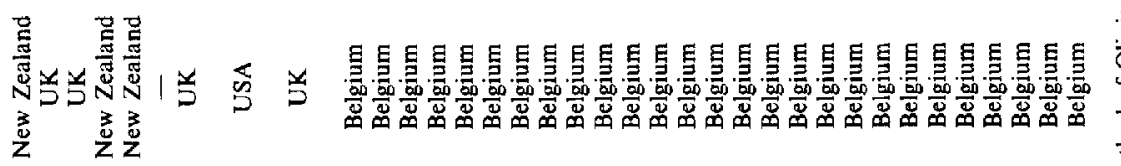

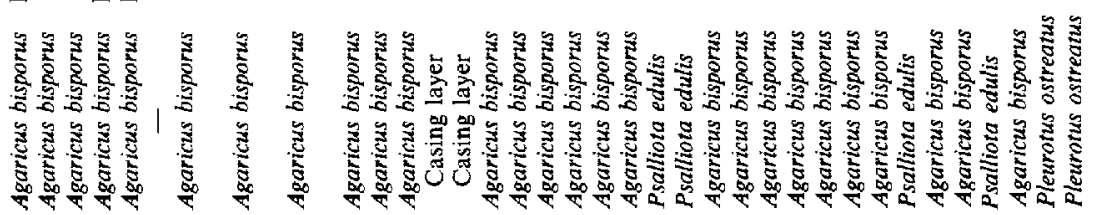

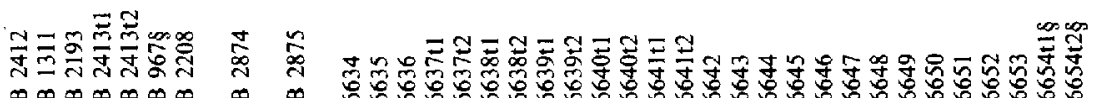

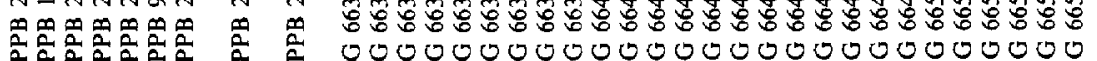

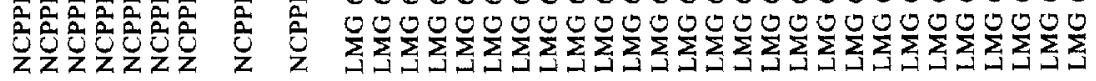

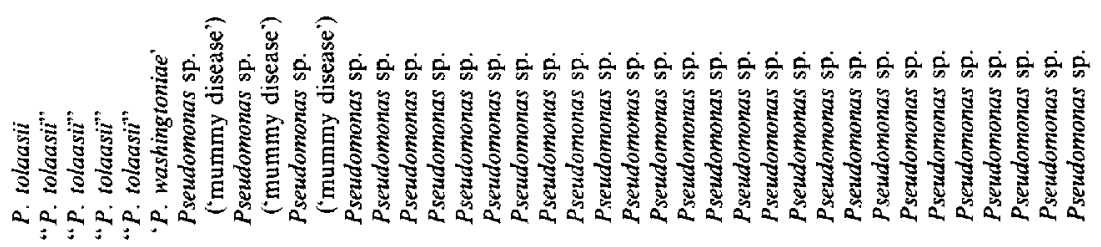

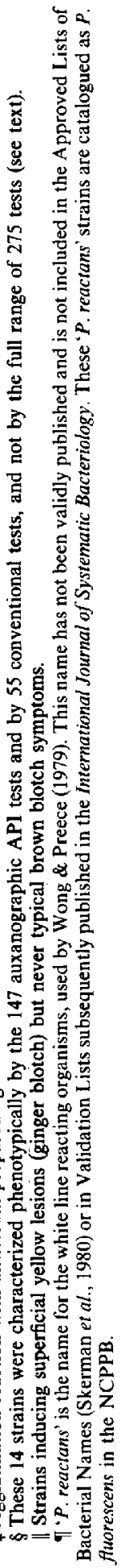




\section{RESULTS}

\section{Phenotypic characters and numerical analysis}

After numerical analysis of the 275 phenotypic features by the unweighted average pair-group method, seven phenons could be delineated (Fig. 1). Phenon I comprised the four strains of $P$. aeruginosa and seemed to be quite homogeneous, with a mean similarity of $93 \% S$. Phenons II and III consisted respectively of three strains of $P$. fluorescens biovar II and all four strains of ' $P$. gingeri'. The main group was formed by phenon IV, comprising eight named $P$. tolaasii strains and 15 organisms isolated from Belgian mushroom farms. All the culture collection strains of $P$. tolaasii, including the type strain NCPPB $2192^{\mathrm{T}}$, were isolated from Agaricus bisporus, whereas the isolates from Belgium came from a broader spectrum, namely Agaricus bisporus (10 strains), Psalliota edulis (2 strains), Pleurotus ostreatus (2 strains) and casing layer (1 strain). Regardless of their different origin all these strains formed a very tight phenotypic group (mean similarity $89 \%$ $S$ ). Phenon V consisted of eleven organisms isolated from cultivated mushrooms in Belgium, one misnamed "P. tolaasii" strain (NCPPB 1311) (Wong \& Preece, 1979), 'P. washingtoniae' NCPPB 967, together with three different colony types of the reference strain of ' $P$. reactans' NCPPB 3149. The latter name, however, has never been validly published, and is a nomen nudum. Phenon VI comprised two of the three mummy disease organisms, NCPPB 2874 and NCPPB 2875. Eight of the nine P. agarici strains clustered together in phenon VII. Some strains did not belong in any of the seven phenons: one of our own isolates from Psalliota edulis (LMG 6652), the type strain of $P$. fluorescens MMCA $40^{\mathrm{T}}$, three misnamed " $P$. tolaasii" strains NCPPB 2193 and NCPPB 2413tl and t2, the mummy disease organism NCPPB 2208 and one misnamed "P. agarici" strain NCPPB 2304. The two types $t 1$ and $t 2$ of NCPPB 2413 differed only in their colony morphology. An extensive description of the different phenotypic characteristics for each phenon is given in Tables 2 and 3. These tables show that each phenon could be distinguished by several phenotypic tests. The two most similar phenons, i.e. phenon IV and phenon V, differed in four features: growth on L-arabinose $(-,+)$, rhamnose $(-,+)$, 5 -ketogluconate $(+,-)$ and acid production from rhamnose $(-,+)$.

\section{Pathogenicity, white line reaction and serology}

The results of the pathogenic reaction on Agaricus bisporus Somycel 53, the white line reactions with $P$. tolaasii NCPPB $2192^{\mathrm{T}}$ and NCPPB 1311 , and the agglutination with the antiserum prepared against the type strain of $P$. tolaasii NCPPB $2192^{\mathrm{T}}$ are summarized in Table 1. Eight $P$. tolaasii culture collection strains (belonging to phenon IV), nine of our own isolates from phenon IV and strain $P$. aeruginosa NCPPB 2197 (phenon I), induced brown blotch symptoms on Agaricus bisporus. The same strains, with the exception of NCPPB 2197 and isolates LMG 6634 and LMG 6635, also gave a white line precipitation band with the white line reacting organism NCPPB 1311 (phenon V). The antiserum prepared against $P$. tolaasii NCPPB $2192^{\mathrm{T}}$ agglutinated all strains of phenon IV with the exception of LMG 6639t1. Cross reactions occurred with 'P. gingeri' NCPPB $3146 \mathrm{t}$, NCPPB 2208 (a mummy disease organism) and LMG 6652 (from Psalliota edulis). All strains of phenon V, together with the ungrouped strain LMG 6652, formed a white line precipitation band with the type strain of $P$. tolaasii NCPPB $2192^{\mathrm{T}}$. The former strains were further characterized by a negative pathogenic and serological reaction. All strains not mentioned above were negative in all three tests.

\section{Comparison of the gel electrophoretic protein patterns}

Normalized photographs of the electrophoregrams of representative members of each phenotypic group are shown in Fig. 2. Phenons I, III, IV, VI and VII seemed to be very homogeneous with respect to their gel electrophoretic protein patterns. However, phenon II and particularly phenon $\mathrm{V}$ were extremely heterogeneous. Within phenon $\mathrm{V}$, seven strains (LMG 6636, LMG 6643, LMG 6645, LMG 6647, LMG 6648, LMG 6651 and LMG 6653) could be differentiated from the others by the presence of a heavy protein band in their gel electrophoregrams. All remaining strains of this phenon showed a low degree of similarity in their gel electrophoretic patterns. The strains occupying a separate position in the phenotypic 


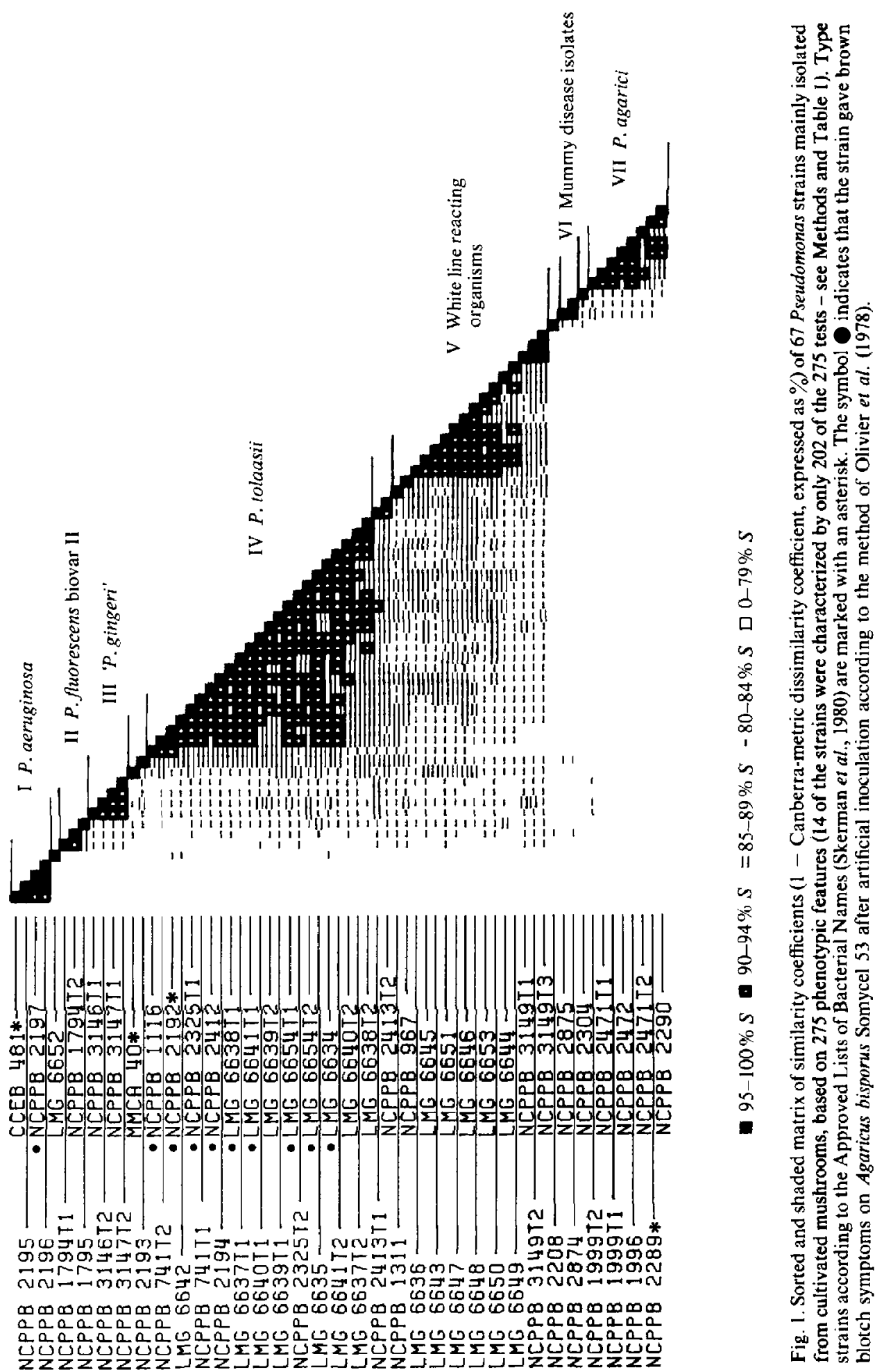


Table 2. Phenotypic features of 67 Pseudomonas strains, mostly from cultivated mushrooms

The percentage frequency of present features in phenons and unclustered strains is given. Results for the tests common to all 67 strains are given in the footnote. NT, Not tested.

Feature

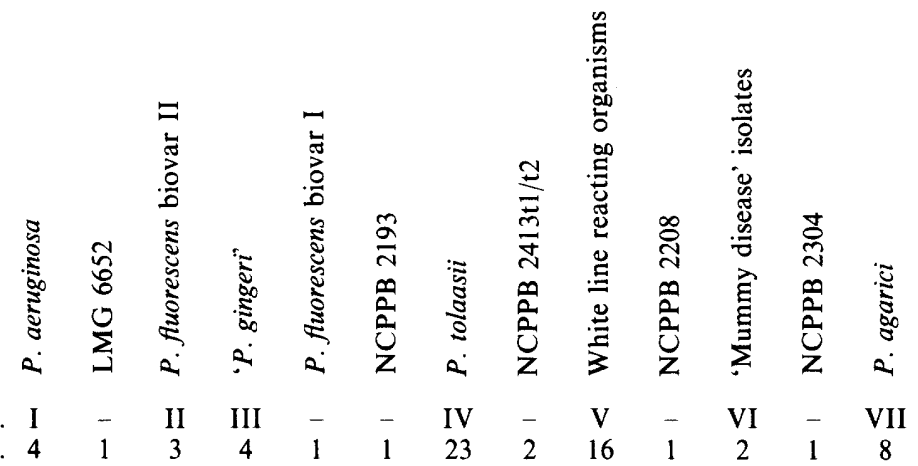

Growth in API 50CH on:

\begin{tabular}{|c|c|c|c|c|c|c|c|c|c|c|c|c|c|}
\hline Erythritol & 0 & 0 & 100 & 100 & 100 & 100 & 100 & 100 & 100 & 0 & 0 & 0 & \\
\hline L-Arabinose & 0 & 0 & 100 & 0 & 100 & 100 & 0 & 100 & 100 & 100 & 100 & 100 & \\
\hline D-Xylose & 0 & 0 & 100 & 100 & 100 & 100 & 0 & 0 & 94 & 100 & 100 & 100 & \\
\hline Adonitol & 0 & 0 & 0 & 25 & 100 & 100 & 100 & 100 & 100 & 0 & 0 & 0 & \\
\hline D-Galactose & 0 & 0 & 100 & 100 & 100 & 100 & 100 & 100 & 100 & 100 & 100 & 100 & 50 \\
\hline D-Fructose & 100 & 100 & 100 & 100 & 100 & 100 & 100 & 100 & 100 & 100 & 100 & 100 & 75 \\
\hline D-Mannose & 0 & 100 & 100 & 100 & 100 & 100 & 100 & 100 & 100 & 100 & 100 & 100 & 5 \\
\hline L-Rhamnose & 0 & 0 & 67 & 0 & 0 & 0 & 0 & $\mathbf{0}$ & 100 & 0 & 0 & 0 & \\
\hline meso-Inositol & 0 & 0 & 100 & 100 & 100 & 100 & 100 & 100 & 100 & 0 & 0 & 0 & 5 \\
\hline Sorbitol & 0 & 0 & 100 & 100 & 100 & 100 & 100 & 100 & 100 & 0 & 0 & 0 & \\
\hline$N$-Acetylglucosamine & 100 & 0 & 100 & 100 & 100 & 100 & 100 & 100 & 100 & 100 & 0 & 0 & \\
\hline Sucrose & 0 & 0 & 100 & 0 & 100 & 100 & 0 & 0 & 0 & 0 & 0 & 0 & \\
\hline Trehalose & 25 & 100 & 100 & 100 & 100 & 100 & 100 & 100 & 100 & 100 & 100 & 0 & 0 \\
\hline Xylitol & 0 & 0 & 0 & 100 & 100 & 100 & 96 & 100 & 100 & 0 & 0 & 0 & \\
\hline D-Lyxose & 0 & 0 & 100 & 100 & 100 & 100 & 100 & 100 & 100 & 100 & 0 & 100 & \\
\hline L-Arabitol & 0 & 0 & 0 & 0 & 100 & 100 & 100 & 100 & 100 & 0 & 0 & 0 & \\
\hline 2-Ketogluconate & 100 & 0 & 100 & 0 & 100 & 100 & 100 & 100 & 100 & 100 & 100 & 0 & \\
\hline 5-Ketogluconate & 0 & 0 & 100 & 50 & 100 & 100 & 100 & 100 & 0 & 0 & 0 & 0 & \\
\hline \multicolumn{14}{|l|}{ Growth in API $50 \mathrm{AO}$ on } \\
\hline Acetate & 100 & 100 & 100 & 100 & 100 & 100 & 100 & 100 & 100 & 100 & 100 & 100 & \\
\hline Butyrate & 100 & 100 & 100 & 50 & 100 & 100 & 100 & 100 & 88 & 100 & 100 & 0 & 0 \\
\hline Isobutyrate & 100 & 100 & 100 & 100 & 100 & 100 & 100 & 100 & 100 & 100 & 100 & 0 & 8 \\
\hline$n$-Valerate & 100 & 100 & 100 & 100 & 100 & 100 & 100 & 100 & 100 & 100 & 100 & 0 & \\
\hline Isovalerate & 100 & 100 & 100 & 0 & 100 & 0 & 57 & 0 & 63 & 100 & 0 & 0 & \\
\hline$n$-Caproate & 100 & 100 & 100 & 100 & 100 & 100 & 100 & 100 & 100 & 100 & 100 & 100 & \\
\hline Maleate & 0 & 0 & 0 & 50 & 0 & 0 & 0 & 0 & 0 & 0 & 0 & 0 & \\
\hline Adipate & 100 & 0 & 0 & 0 & 0 & 0 & 0 & 100 & 56 & 0 & 0 & 0 & \\
\hline Azelate & 100 & 0 & 0 & 0 & 0 & 0 & 0 & 0 & 0 & 0 & 0 & 0 & \\
\hline Sebacate & 100 & 0 & 0 & 0 & 100 & 0 & 0 & 50 & 0 & 0 & 0 & 0 & 13 \\
\hline D-Malate & 25 & 100 & 67 & 75 & 0 & 0 & 52 & 100 & 81 & 0 & 100 & 100 & 63 \\
\hline D-Tartrate & 0 & 0 & 67 & 0 & 0 & 0 & 0 & 0 & 0 & 100 & 100 & 100 & \\
\hline L-Tartrate & 0 & 0 & 0 & 0 & 0 & 0 & 0 & 0 & 38 & 0 & 100 & 0 & \\
\hline meso-Tartrate & 0 & 100 & 0 & 100 & 100 & 100 & 100 & 100 & 100 & 0 & 100 & 100 & \\
\hline Laevulinate & 100 & 0 & 67 & 100 & 100 & 100 & 57 & 100 & 94 & 100 & 0 & 100 & \\
\hline Citraconate & 0 & 100 & 67 & 100 & 0 & 0 & 91 & 100 & 94 & 100 & 50 & 0 & 7 \\
\hline Itaconate & 100 & 100 & 100 & 100 & 100 & 100 & 100 & 100 & 100 & 0 & 100 & 0 & 100 \\
\hline Mesaconate & 100 & 100 & 100 & 100 & 100 & 100 & 100 & 100 & 100 & 0 & 100 & 0 & 100 \\
\hline Aconitate & 0 & 0 & 33 & 100 & 100 & 100 & 100 & 100 & 100 & 100 & 0 & 0 & \\
\hline Phenylacetate & 0 & 100 & 0 & 0 & 0 & 0 & 0 & 0 & 0 & 0 & 0 & 0 & \\
\hline Benzoate & 100 & 0 & 0 & 0 & 0 & 0 & 0 & 0 & 69 & 0 & 0 & 0 & \\
\hline 4-Hydroxybenzoate & 100 & 100 & 67 & 100 & 100 & 100 & 100 & 100 & 94 & 0 & 0 & 0 & \\
\hline Phthalate & 0 & 0 & 0 & 0 & 0 & 0 & 0 & 0 & 0 & 0 & 100 & 0 & \\
\hline Terephthalate & 0 & 0 & 0 & 0 & 0 & 0 & 0 & 0 & 0 & 0 & 100 & 0 & \\
\hline
\end{tabular}


Table 2 (continued)

Growth in API 50AA on:

Glycine

L-Norleucine

DL-Norvaline

DL-2-Aminobutyrate

L-Methionine

L-Tryptophan

Trigonelline

L-Ornithine

L-Lysine

L-Citrulline

DL-Kynurenine

DL-3-Aminobutyrate

DL-5-Aminovalerate

2-Aminobenzoate

Acetamide

Sarcosine

Butylamine

Amylamine

Ethanolamine

Histamine

Glucosamine

Colonies on YPGA medium

White

Cream

Yellow-brown

Yellow

Smooth

Irregular

Raised to convex

Diameter $<3 \mathrm{~mm}$

Cells:

Elongated

Filamentous

Diameter $\leqslant 2 \mu \mathrm{m}$

Sensitivity to:

Chloramphenicol $(30 \mu \mathrm{g})$

Novobiocin $(30 \mu \mathrm{g})$

Fusidic acid $(10 \mu \mathrm{g})$

Gentamicin $(10 \mu \mathrm{g})$

Tobramycin $(10 \mu \mathrm{g})$

Neomycin $(10 \mu \mathrm{g})$

Streptomycin $(10 \mu \mathrm{g})$

Nalidixic acid $(30 \mu \mathrm{g})$

Kanamycin $(30 \mu \mathrm{g})$

Tetracycline $(30 \mu \mathrm{g})$

Fluorescence on:

King A medium

King B medium

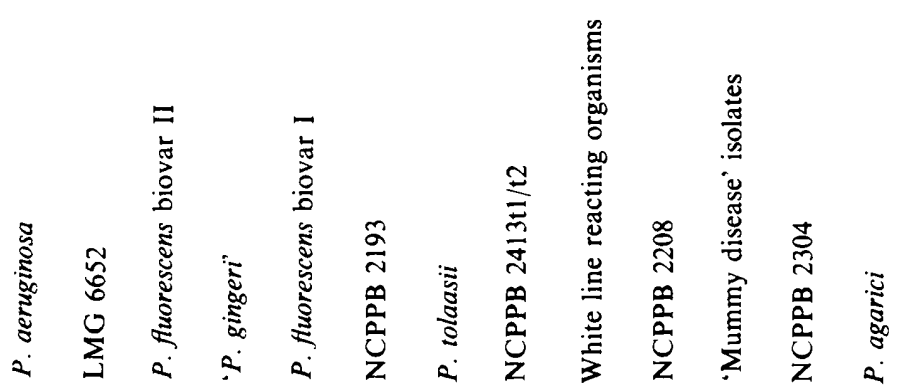

$\begin{array}{rrrrrrrrrrrrr}0 & 0 & 0 & 0 & 0 & 0 & 0 & 0 & 13 & 100 & 0 & 0 & 0 \\ 0 & 0 & 0 & 0 & 100 & 0 & 4 & 0 & 6 & 100 & 0 & 0 & 0 \\ 100 & 100 & 0 & 75 & 0 & 100 & 86 & 100 & 50 & 0 & 50 & 100 & 88\end{array}$

$\begin{array}{rrrrrrrrrrrrr}0 & 0 & 0 & 0 & 0 & 0 & 0 & 0 & 19 & 0 & 50 & 0 & 0 \\ 0 & 0 & 0 & 0 & 0 & 0 & 22 & 0 & 6 & 0 & 0 & 0 & 0 \\ 0 & 0 & 0 & 0 & 100 & 0 & 9 & 0 & 6 & 0 & 0 & 0 & 0 \\ 0 & 0 & 0 & 50 & 0 & 0 & 0 & 0 & 0 & 0 & 0 & 0 & 88 \\ 0 & 0 & 0 & 75 & 0 & 0 & 0 & 0 & 0 & 0 & 0 & 0 & 100 \\ 0 & 0 & 0 & 100 & 0 & 0 & 9 & 0 & 0 & 0 & 0 & 100 & 88 \\ 0 & 0 & 67 & 50 & 0 & 0 & 9 & 0 & 13 & 0 & 0 & 100 & 100 \\ 0 & 100 & 0 & 0 & 100 & 100 & 83 & 100 & 75 & 0 & 0 & 0 & 0 \\ 0 & 100 & 100 & 100 & 100 & 100 & 74 & 50 & 81 & 100 & 100 & 100 & 100 \\ 50 & 100 & 100 & 100 & 100 & 100 & 100 & 100 & 100 & 100 & 50 & 100 & 100\end{array}$

$\begin{array}{lllllllllllll}100 & 0 & 0 & 0 & 0 & 0 & 0 & 0 & 6 & 0 & 0 & 0 & 0\end{array}$ $\begin{array}{lllllllllllll}100 & 100 & 33 & 25 & 100 & 100 & 100 & 100 & 100 & 0 & 0 & 0 & 100\end{array}$ 


\begin{tabular}{|c|c|c|c|c|c|c|c|c|c|c|c|c|c|}
\hline & 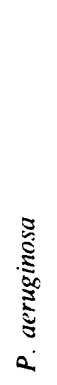 & $\begin{array}{l}\tilde{\sigma} \\
8 \\
0 \\
\vdots \\
\vdots\end{array}$ & 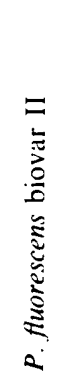 & 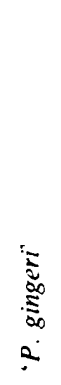 & 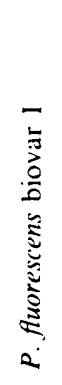 & 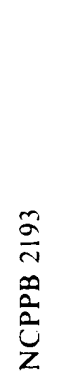 & 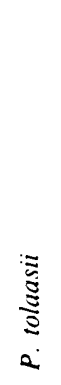 & 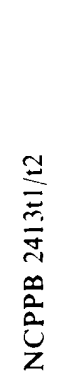 & 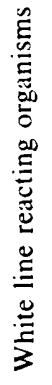 & 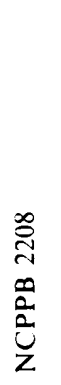 & 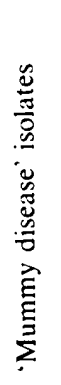 & 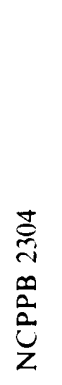 & 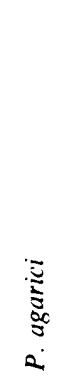 \\
\hline Reduction of nitrate & 100 & 100 & 100 & 0 & 0 & 0 & 0 & 0 & 0 & 0 & 0 & 0 & 0 \\
\hline $\begin{array}{l}\text { Growth in the presence of } \mathrm{NaCl} \text { : } \\
3 \% \\
4 \% \\
5 \% \\
6 \% \\
7 \%\end{array}$ & $\begin{array}{l}100 \\
100 \\
100 \\
100 \\
100\end{array}$ & $\begin{array}{r}100 \\
100 \\
100 \\
100 \\
0\end{array}$ & $\begin{array}{r}100 \\
67 \\
0 \\
0 \\
0\end{array}$ & $\begin{array}{r}100 \\
0 \\
0 \\
0 \\
0\end{array}$ & $\begin{array}{r}100 \\
100 \\
0 \\
0 \\
0\end{array}$ & $\begin{array}{r}100 \\
100 \\
100 \\
0 \\
0\end{array}$ & $\begin{array}{r}100 \\
100 \\
4 \\
0 \\
0\end{array}$ & $\begin{array}{r}100 \\
100 \\
0 \\
0 \\
0\end{array}$ & $\begin{array}{r}81 \\
69 \\
0 \\
0 \\
0\end{array}$ & $\begin{array}{r}100 \\
100 \\
0 \\
0 \\
0\end{array}$ & $\begin{array}{r}100 \\
100 \\
100 \\
0 \\
0\end{array}$ & $\begin{array}{r}100 \\
100 \\
0 \\
0 \\
0\end{array}$ & $\begin{array}{l}0 \\
0 \\
0 \\
0 \\
0\end{array}$ \\
\hline $\begin{array}{l}\text { Growth at: } \\
33^{\circ} \mathrm{C} \\
37^{\circ} \mathrm{C} \\
39^{\circ} \mathrm{C} \\
41^{\circ} \mathrm{C}\end{array}$ & $\begin{array}{l}100 \\
100 \\
100 \\
100\end{array}$ & $\begin{array}{r}100 \\
100 \\
0 \\
0\end{array}$ & $\begin{array}{r}100 \\
0 \\
0 \\
0\end{array}$ & $\begin{array}{r}100 \\
0 \\
0 \\
0\end{array}$ & $\begin{array}{r}100 \\
0 \\
0 \\
0\end{array}$ & $\begin{array}{r}100 \\
0 \\
0 \\
0\end{array}$ & $\begin{array}{r}100 \\
0 \\
0 \\
0\end{array}$ & $\begin{array}{r}100 \\
0 \\
0 \\
0\end{array}$ & $\begin{array}{r}94 \\
0 \\
0 \\
0\end{array}$ & $\begin{array}{r}100 \\
100 \\
0 \\
0\end{array}$ & $\begin{array}{r}100 \\
0 \\
0 \\
0\end{array}$ & $\begin{array}{l}0 \\
0 \\
0 \\
0\end{array}$ & $\begin{array}{r}100 \\
0 \\
0 \\
0\end{array}$ \\
\hline
\end{tabular}

The following phenotypic features were present in all 67 strains: rounded, motile Gram-negative rods; moderate to extensive growth on YPGA; oxidase and catalase activity; growth in the API system on glycerol, Dribose, D-glucose, D-mannitol, D-arabitol, D-gluconate, propionate, heptanoate, caprylate, pelargonate, caprate, malonate, succinate, fumarate, glutarate, DL-lactate, DL-glycerate, DL-3-hydroxybutyrate, L-malate, pyruvate, 2-oxoglutarate, citrate, D- $\alpha$-alanine, L- $\alpha$-alanine, L-leucine, L-isoleucine, L-valine, L-serine, L-threonine, L-phenylalanine, L-tyrosine, L-histidine, L-aspartate, L-glutamate, L-arginine, L-proline, betaine, $\beta$-alanine, DL-4-aminobutyrate, diaminobutane, spermine.

The following phenotypic features were absent in all 67 strains: sensitivity to $10 \mathrm{U}$ penicillin $\mathrm{G}, 10 \mu \mathrm{g}$ erythromycin, $10 \mu \mathrm{g}$ ampicillin, $2 \mu \mathrm{g}$ lincomycin, $200 \mu \mathrm{g}$ nitrofurantoin, $10 \mathrm{U}$ bacitracin, $10 \mu \mathrm{g}$ methicillin, $10 \mu \mathrm{g}$ colistin sulphate, $25 \mu \mathrm{g}$ cephaloridine, $300 \mathrm{U}$ polymyxin $\mathrm{B}, 100 \mu \mathrm{g}$ sulphafurazole, $25 \mu \mathrm{g}$ mecillinam, $30 \mu \mathrm{g}$ cephradine; growth in the API system on D-arabinose, $\mathrm{L}$-xylose, methyl $\beta$-D-xyloside, L-sorbose, dulcitol, methyl $\alpha$ $D$-mannoside, methyl $\alpha$-D-glucoside, amygdalin, arbutin, aesculin, salicin, D-cellobiose, maltose, lactose, Dmelibiose, inulin, D-melezitose, D-raffinose, starch, glycogen, $\beta$-gentiobiose, D-turanose, D-tagatose, D-fucose, Lfucose, oxalate, pimelate, suberate, glycolate, 2-hydroxybenzoate, 3-hydroxybenzoate, D-mandelate, L-mandelate, isophthalate, L-cysteine, D-tryptophan, creatine, 3-aminobenzoate, 4-aminobenzoate, urea, ethylamine, tryptamine, benzylamine.

analysis (Fig. 1), i.e. LMG 6652, MMCA 40", NCPPB 2193, NCPPB 2413t 1 and $t 2$, NCPPB 2208 and NCPPB 2304, also showed aberrant protein gel electrophoregrams.

\section{DNA : DNA hybridizations}

DNA : DNA hybridization experiments revealed that within phenon IV all strains tested (NCPPB 2192 ${ }^{\mathrm{T}}$, NCPPB 741t1, LMG 6641tl and LMG 6641t2) were closely related (DNA binding $98-100 \% D$ ). A clear genotypic diversity existed among strains from phenon $V$ (DNA binding $41-90 \% D$ ). Strains LMG 6643 and LMG 6647, both belonging in phenon V and displaying identical protein electrophoregrams, were also genotypically highly related $(90 \% \mathrm{D})$. DNA of the strains of phenon $V$ that had different gel electrophoretic patterns, i.e. NCPPB 1311, NCPPB 967, NCPPB 3149t1 and LMG 6646, yielded DNA binding values of respectively $52 \%, 68 \%, 70 \%$ and $81 \% D$ when hybridized with DNA of strain LMG 6643 . DNA of 'P. reactans' NCPPB 3149t1 hybridized with DNA of strains NCPPB 1311, NCPPB 967 and LMG 6646 yielded values of $58 \%, 62 \%$ and $63 \% \mathrm{D}$, respectively. Within phenon $\mathrm{V}$ the lowest DNA binding value was found between strains NCPPB 1311 and LMG $6646(41 \% D)$. 


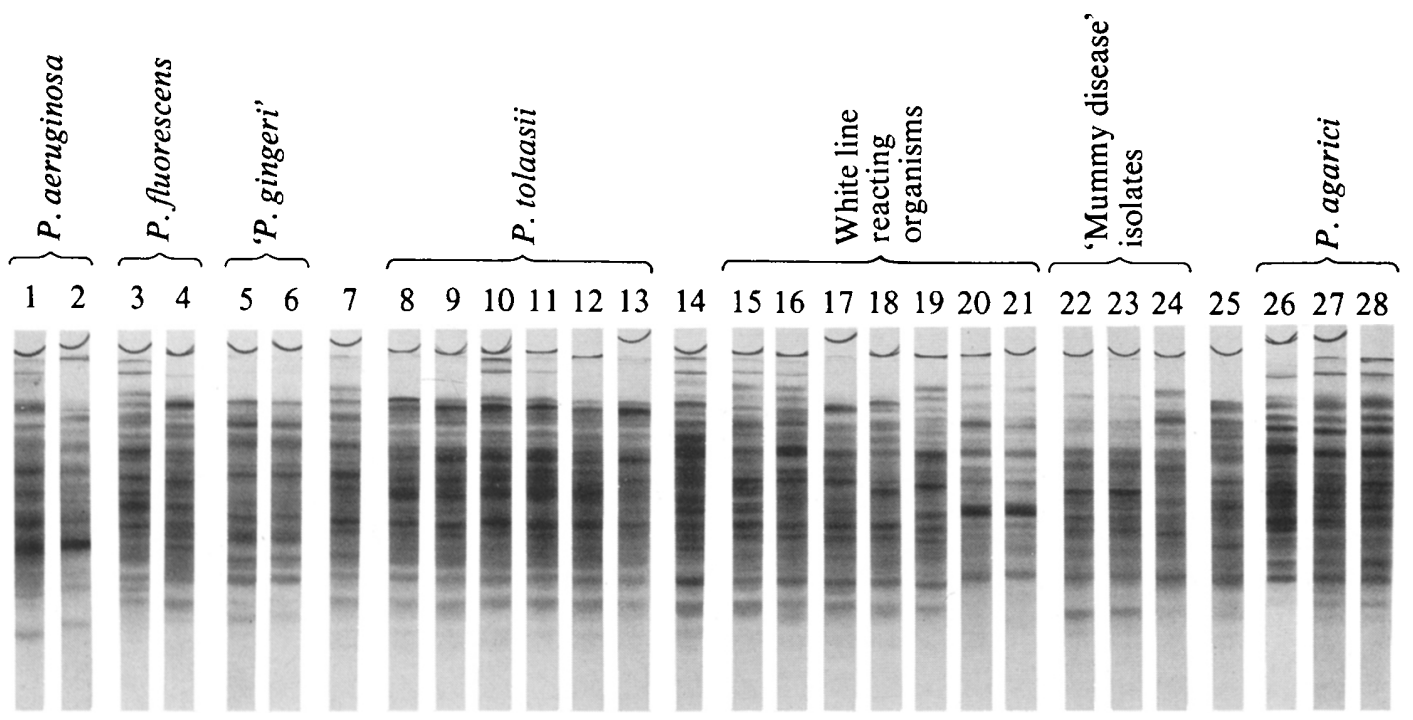

Fig. 2. Normalized photographs of the protein gel electrophoregrams of representative members of the different gel electrophoretic groups. Lanes 1 and 2, $P$. aeruginosa CCEB $481^{\top}$ and NCPPB 2197; lanes 3 and $4, P$. fluorescens biovar I MMCA $40^{\mathrm{T}}$ and $P$. fluorescens biovar II NCPPB $1794 \mathrm{tl}$; lanes 5 and 6, ' $P$. gingeri' NCPPB 3146tl and 12 : lane 7, a misnamed "P. tolaasii" NCPPB 2193; lanes 8-13, P. tolaasii LMG 6641t1, LMG 6641t2, NCPPB 2192 ${ }^{\mathrm{T}}$, LMG 6654t1, NCPPB 2412 and LMG 6634; lane 14, a misnamed " $P$. tolaasii" NCPPB $2413 \mathrm{tl}$; lanes $15-21$, the white line reacting organisms ' $P$. reactans' NCPPB 3149tl, a misnamed "P. tolaasii" NCPPB 1311, 'P. washingtoniae' NCPPB 967, and our own isolates LMG 6649, LMG 6646, LMG 6643 and LMG 6647; lanes 22-24, 'mummy disease' isolates NCPPB 2874, NCPPB 2875 and NCPPB 2208; lane 25, a misnamed “P. agarici" NCPPB 2304; lanes 2628 , $P$. agarici NCPPB $2289^{\mathrm{T}}$, NCPPB $2471 \mathrm{t} 1$ and $\mathrm{t} 2$.

Hybridization between strains of phenons IV and $\mathrm{V}$ gave values ranging from $31 \% D$ (between strains NCPPB $2192^{\mathrm{T}}$ and LMG 6643) to $44 \% D$ (between strains NCPPB $2192^{\mathrm{T}}$ and LMG 6646). DNA binding values between strains from phenon IV or phenon $V$ and representative strains of the other phenons did not exceed $50 \% D$. This was also the case for the two misnamed "P. tolaasii" strains NCPPB 2193 and NCPPB 2413t1, which showed a DNA binding value of respectively $46 \%$ and $32 \% D$ with $P$. tolaasii NCPPB $2192^{\mathrm{T}}$.

\section{DISCUSSION}

Pseudomonas tolaasii

In our opinion $P$. tolaasii should be restricted to phenon IV, comprising 23 closely related strains including the type strain $P$. tolaasii NCPPB $2192^{\mathrm{T}}$. The high relatedness of the strains was shown by phenotypic analysis, gel electrophoretic comparisons and DNA:DNA hybridizations. From this viewpoint $P$. tolaasii corresponded to group A of Wong \& Preece (1979) and to the blotching group of Zarkower et al. (1984), but was not congruent with the $P$. tolaasii group defined by Fahy (1981), which included both blotching and non-pathogenic strains. The latter comprised strains clustering in our phenon V. A complete description of the phenotypic features of $P$. tolaasii is given in Tables 2 and 3.

In Bergey's Manual of Systematic Bacteriology, Palleroni (1984) referred for the definition of $P$. tolaasii to the original description by Paine (1919), comprising 22 features which - unfortunately - were also common to many other Pseudomonas species. All strains of our phenon IV showed these features, except for the alkalinization of litmus milk. From the features given in the original description by Paine (1919) the pathogenicity on mushrooms seemed to be the only reliable one to identify $P$. tolaasii. Of the $23 P$. tolaasii strains (phenon IV), six were avirulent on 
Table 3. Phenotypic features of 53 Pseudomonas strains, mostly from cultivated mushrooms

The percentage frequency of present features in phenons and unclustered strains is given. Results for the tests common to all 53 strains are given in the footnote. NT, Not tested.

\begin{tabular}{|c|c|c|c|c|c|c|c|c|c|c|c|}
\hline & 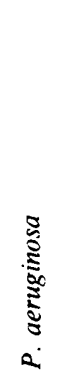 & 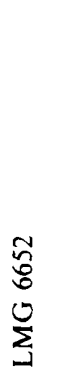 & 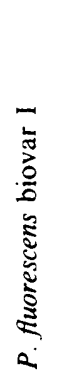 & 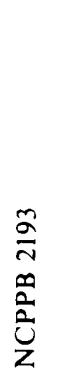 & 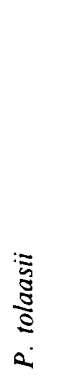 & 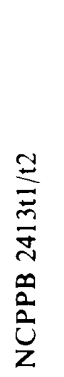 & 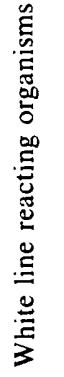 & 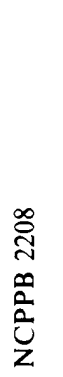 & 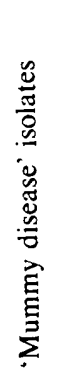 & 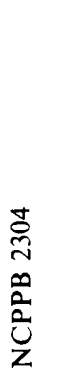 & $\begin{array}{l}\tilde{E} \\
\overline{5} \\
8 \\
0 \\
0\end{array}$ \\
\hline Phenon. & 1 & - & - & - & IV & - & $\mathrm{V}$ & - & VI & - & VII \\
\hline No. of strains . & 3 & 1 & 1 & 1 & 21 & 2 & 12 & 1 & 2 & 1 & 8 \\
\hline Oxidative glucose metabolism $(\mathrm{O} / \mathrm{F})$ & 100 & 100 & 100 & 100 & 100 & 100 & 100 & 100 & 100 & 100 & 75 \\
\hline $\mathrm{H}_{2} \mathrm{~S}$ production from cysteine & 0 & 0 & 0 & 0 & 0 & 0 & 0 & 0 & 100 & 100 & 100 \\
\hline Arginine dihydrolase & 100 & 100 & 100 & 100 & 100 & 100 & 100 & 100 & 100 & 0 & 0 \\
\hline Levan production from sucrose & 0 & 0 & 100 & 0 & 0 & 0 & 0 & 0 & 0 & 0 & 0 \\
\hline \multicolumn{12}{|l|}{ Hydrolysis of: } \\
\hline Casein & 100 & 100 & 100 & 100 & 76 & 0 & 67 & 0 & 0 & NT & 0 \\
\hline Tween 80 & 100 & 100 & 100 & 100 & 100 & 100 & 92 & 100 & 100 & 100 & 100 \\
\hline \multicolumn{12}{|l|}{ Acid production from: } \\
\hline Dulcitol & 0 & 100 & 0 & 0 & 0 & 0 & 0 & 0 & 0 & 0 & 0 \\
\hline D-Arabinose & 100 & 0 & 0 & 0 & 0 & 0 & 25 & 100 & 0 & 0 & 0 \\
\hline L-Rhamnose & 0 & 0 & 0 & 0 & 0 & 0 & 100 & 0 & 0 & 0 & 0 \\
\hline D-Lactose & 0 & 0 & 0 & 0 & 0 & 0 & 17 & 0 & 0 & 0 & 0 \\
\hline Sucrose & 0 & 0 & 100 & 0 & 0 & 0 & 0 & 0 & 0 & 0 & 0 \\
\hline D-Trehalose & 0 & 100 & 0 & 0 & 0 & 0 & 58 & 0 & 0 & 0 & 0 \\
\hline D-Fructose & 33 & 0 & 0 & 100 & 29 & 100 & 25 & 100 & 100 & 0 & 63 \\
\hline Melibiose & 100 & 100 & 0 & 0 & 0 & 0 & 58 & 100 & 0 & 0 & 0 \\
\hline Inulin & 0 & 100 & 0 & 0 & 0 & 0 & 25 & 0 & 0 & 0 & 0 \\
\hline Adonitol & 0 & 0 & 100 & 0 & 19 & 100 & 75 & 0 & 0 & 0 & 0 \\
\hline meso-Inositol & 0 & 0 & 0 & 0 & 20 & 0 & 50 & 0 & 0 & 0 & 75 \\
\hline D-Xylose & 100 & 100 & 100 & 100 & 90 & 100 & 100 & 100 & 100 & 100 & 0 \\
\hline D-Glucose & 100 & 100 & 100 & 100 & 100 & 100 & 100 & 100 & 100 & 0 & 88 \\
\hline D-Ribose & 100 & 100 & 100 & 100 & 100 & 100 & 100 & 100 & 100 & 0 & 100 \\
\hline D-Mannose & 100 & 100 & 100 & 100 & 100 & 100 & 100 & 100 & 100 & 0 & 87 \\
\hline D-Mannitol & 100 & 100 & 100 & 100 & 57 & 100 & 92 & 0 & 100 & 100 & 100 \\
\hline \multicolumn{12}{|l|}{ Litmus milk: } \\
\hline Acid production & 0 & 100 & 0 & 0 & 52 & 0 & 75 & 0 & 0 & 0 & 0 \\
\hline Reduction & 0 & 0 & 0 & 0 & 29 & 50 & 17 & 0 & 0 & 0 & 0 \\
\hline Alkalinization & 0 & 0 & 100 & 100 & 19 & 50 & 8 & 100 & 100 & 100 & 100 \\
\hline Coagulation & 100 & 0 & 0 & 0 & 14 & 0 & 75 & 0 & 0 & 0 & 0 \\
\hline Peptonization & 100 & 0 & 0 & 0 & 0 & 0 & 0 & 0 & 0 & 0 & 0 \\
\hline \multicolumn{12}{|l|}{ Alkalinization of: } \\
\hline Sodium acetate & 100 & 100 & 100 & 100 & 100 & 100 & 100 & 0 & 0 & 0 & 25 \\
\hline Sodium benzoate & 100 & 0 & 0 & 0 & 0 & 0 & 8 & 0 & 0 & 0 & 0 \\
\hline Sodium formate & 100 & 0 & 0 & 0 & 0 & 0 & 8 & 0 & 0 & 0 & 0 \\
\hline Sodium citrate & 100 & 100 & 100 & 100 & 100 & 100 & 100 & 100 & 0 & 100 & 100 \\
\hline Sodium tartrate & 0 & 0 & 0 & 0 & 0 & 0 & 25 & 0 & 100 & 0 & 0 \\
\hline D-Galacturonic acid & 0 & 0 & 0 & 0 & 0 & 0 & 0 & 100 & 100 & 0 & 0 \\
\hline Propionic acid & 100 & 100 & 0 & 0 & 57 & 100 & 8 & 0 & 0 & 0 & 0 \\
\hline \multicolumn{12}{|l|}{ Sensitivity to: } \\
\hline Sodium nitrite $(0.01 \%)$ & 0 & 0 & 100 & 0 & 48 & 0 & 58 & 0 & 0 & 0 & 0 \\
\hline Potassium nitrite $(0.01 \%)$ & 0 & 0 & 0 & 100 & 57 & 50 & 8 & 0 & 0 & 0 & 0 \\
\hline Hexamethylenetetramine $(0$ & 0 & 0 & 0 & 0 & 0 & 0 & 0 & 0 & 0 & 100 & 0 \\
\hline Hexamethylenetetramine $(0.2 \%$ & 100 & 0 & 100 & 100 & 71 & 100 & 25 & 100 & 100 & 100 & 100 \\
\hline
\end{tabular}


Streptomycin sulphate $(0.01 \%)$

Kasugamycin $60 \%(0.01 \%)$

CGA 78039 WP $50(0.01 \%)$

CGA 78039 ammonium salt $(0.01 \%)$

Formaldehyde $35 \%(0.01 \%)$

Propyl gallate $(0.2 \%)$

4-Hydroxyethylbenzoate, sodium salt $(0 \cdot 2 \%)$

Sodium benzoate $(0.2 \%)$

Quinine sulphate $(0.2 \%)$

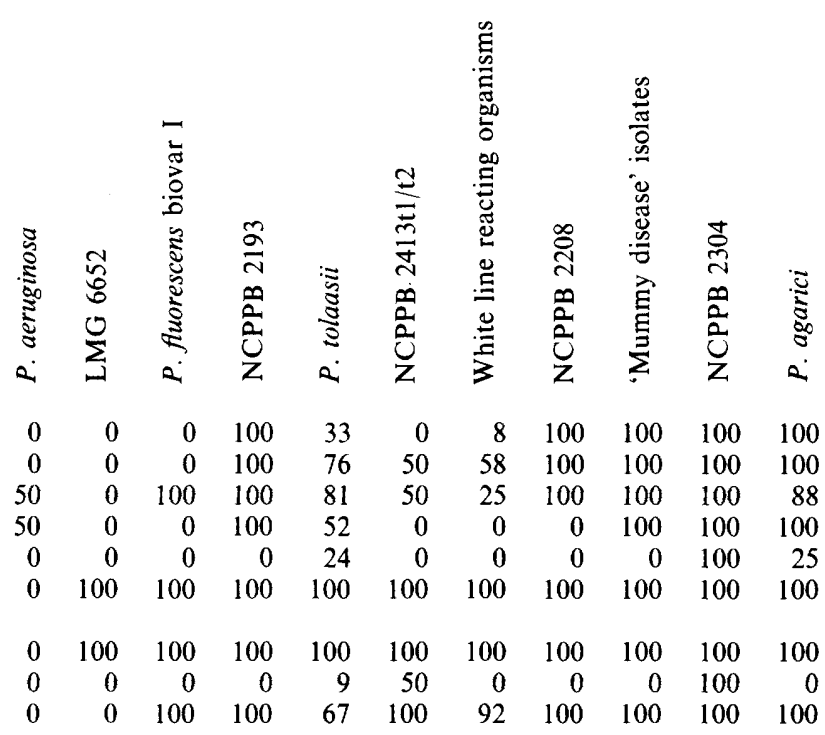

The following phenotypic features were present in all 53 strains: hydrolysis of gelatin and Tween 60; alkalinization of fumarate, succinate, malate, lactate and malonate (sodium salts).

The following phenotypic features were absent in all 53 strains: DNAase activity; ornithine- and lysine decarboxylase activity; hydrolysis of starch and aesculin; production of indole; reducing substances from sucrose; acetoin production; requirement for growth factors; $\beta$-galactosidase activity; acid production from raffinose, starch, dextrin, salicin, $\alpha$-D-melezitose, D-maltose; alkalinization of gluconate and oxalate (sodium salts).

Table 4. White line reaction, pathogenicity and slide agglutination of P. tolaasii strains from phenon $I V$

$\begin{array}{cccc}\begin{array}{c}\text { No. of strains } \\ \text { from phenon IV }\end{array} & \begin{array}{c}\text { White line reaction } \\ \text { against NCPPB 1311 }\end{array} & \begin{array}{c}\text { Pathogenicity on } \\ \text { Agaricus bisporus }\end{array} & \begin{array}{c}\text { Slide agglutination } \\ \text { with antiserum against } \\ \text { NCPPB 2192 }\end{array} \\ 15 & + & + & + \\ 2 & - & + & + \\ 5 & - & - & +\end{array}$

Agaricus bisporus. All these avirulent strains were obtained as colony variants upon subculturing of virulent forms on PAF medium. The existence of different colony types, correlating with virulence differences, was also observed by Olivier et al. (1978) and by Cutri et al. (1984). In our work no gel electrophoretic or major phenotypic differences could be found between the virulent and avirulent forms. Three authors have extended the phenotypic description of $P$. tolaasii (Young, 1970; Fahy, 1981; Zarkower et al., 1984). Our results differed in five features from the 36 described by Young (1970), namely acid production on arabinose, rhamnose and melibiose, lipase activity and growth on $6 \% \mathrm{NaCl}$. Five $P$. tolaasii strains examined by Fahy (1981), namely NCPPB 741, NCPPB 1116, NCPPB 2192 ${ }^{\mathrm{T}}$, NCPPB 2194 and NCPPB 2325, were included in our analysis; the agreement between our results and these of Fahy (1981) was over $95 \%$. Our data agreed completely with those obtained by Zarkower et al. (1984) on four $P$. tolaasii strains (NCPPB 741, NCPPB 1116, NCPPB $2192^{\mathrm{T}}$ and NCPPB 2325).

Wong \& Preece (1979) advocated the use of the white line test for the identification of $P$. tolaasii. From Table 4 it is clear that all strains giving a white line reaction with NCPPB 1311 also gave a pathogenic reaction on Agaricus bisporus and agglutinated with the antiserum against 
Table 5. Phenotypic features useful for the differentiation of the pseudomonads occurring on mushrooms

+ , All strains positive; - , all strains negative.

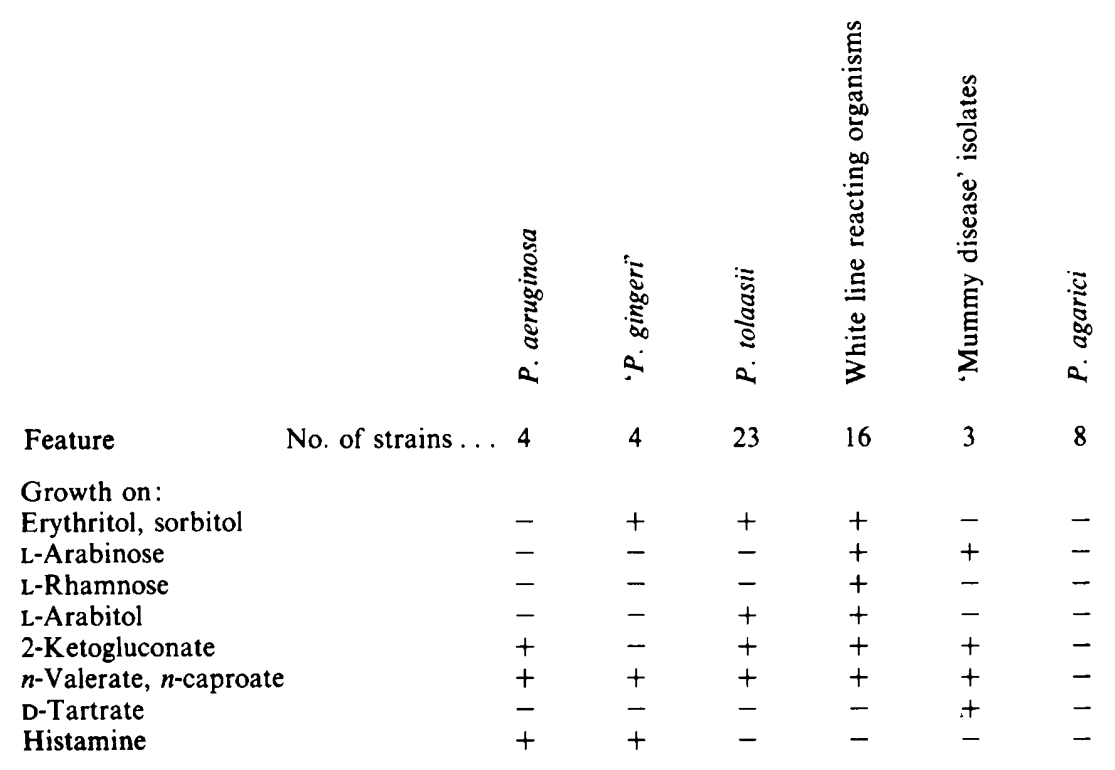

P. tolaasii NCPPB $2192^{\mathrm{T}}$. This confirmed the reliability of the white line reaction for the identification of virulent $P$. tolaasii as stated by Wong \& Preece (1979) and Zarkower et al. (1984). It should be stressed, however, that a negative white line reaction does not rule out the possibility of pathogenic ( 2 strains) or non-pathogenic (6 strains) $P$. tolaasii (Table 4$)$. The latter group contained one strain (LMG 6639t1) showing no pathogenicity on Agaricus bisporus, no white line reaction and no agglutination with the antiserum. Nevertheless this strain undoubtedly belonged in phenon IV as shown by its phenotypic and gel electrophoretic characteristics (Fig. 1, Fig. 2).

In Bergey's Manual of Systematic Bacteriology (Palleroni, 1984) P. tolaasii is included in Section V of the genus Pseudomonas. This section comprises a number of species whose taxonomic position is not well established. In the case of $P$. tolaasii, however, DNA :rRNA hybridizations (De Vos et al., 1985) have clearly shown that it belongs in Section I of the genus Pseudomonas (Palleroni, 1984) and that it is thus a real member of Pseudomonas sensu De Vos \& De Ley (1983). The taxonomic relationships of $P$. tolaasii with the other members of this section remain unclear. By comparing our phenotypic data with those of Stanier et al. (1966), P. tolaasii could best be placed in biotype G (biovar V) of $P$. fluorescens. However, this biotype is very heterogeneous and consists of doubtful $P$. fluorescens strains. Because of the lack of a comprehensive comparative study encompassing reference strains from the genus $P$ seudomonas, in particular members of $P$. fluorescens, we could not draw definite taxonomic conclusions.

\section{Misnamed "P. tolaasii" strains}

Our phenotypic analysis (Fig. 1), protein gel electrophoretic study (Fig. 2) and DNA :DNA hybridizations indicated that the "P. tolaasii" strains NCPPB 2193, NCPPB 2413t 1 and $t 2$, and NCPPB 1311 were not authentic $P$. tolaasii strains, as defined in the preceding section. Wong \& Preece (1979) had already included strain NCPPB 2193 as a member of their saprophytic group C pseudomonads. Strains NCPPB $2413 \mathrm{t} 1$ and $\mathrm{t} 2$ were not examined by Wong \& Preece (1979) but were clearly different from the $P$. tolaasii strains of phenon IV (Tables 2 and 3). Strain NCPPB 1311 was a white line reacting organism clustering in phenon V. 
The white line reacting organisms

In our study the white line reaction against the type strain of $P$. tolaasii was not limited to strains from one single phenotypic group. Indeed strain LMG 6652, which remained phenotypically and gel electrophoretically ungrouped, was also a white line reacting organism. However, here we restrict comment to the so-called white line reacting organisms of phenon $\mathrm{V}$, encompassing ' $P$. washingtoniae', ' $P$. reactans' strains, one misnamed 'P. tolaasii" NCPPB 1311, and 11 of our own isolates. Phenon $V$ was phenotypically rather homogeneous and corresponded to group B of Wong \& Preece (1979) and to set 1 of Zarkower et al. (1984: Table 2). The phenotypic description of our white line reacting organisms can be found in Tables 2 and 3 . However, this group was not very homogeneous in its gel electrophoretic properties or DNA : DNA homologies. The low DNA relatedness of the white line reacting organisms with $P$. tolaasii precludes their inclusion in this species. Preece \& Wong (1982) used the name 'P. reactans' for the white line reacting organisms, but gave no description. This name has no standing in nomenclature according to the International Code of Nomenclature of Bacteria (Lapage et al., 1975). Because of the heterogeneity within this group we are reluctant to draw any taxonomic conclusions.

\section{Phenotypic differentiation of the Pseudomonas species occurring on mushrooms}

Our results show that the unidentified Pseudomonas species of mummy disease, the three pathogenic taxa $P$. tolaasii, $P$. agarici and ' $P$. gingeri', the saprophytic $P$. aeruginosa and the white line reacting organisms can be easily differentiated from each other by several phenotypic tests. A key comprising the most useful diagnostic tests is given in Table 5.

We thank API System, La Balme-les-Grottes, Montalieu-Vercieu, France, for supplying API galleries and Ing. A. Overstijns, Provinciaal Onderzoek- en Voorlichtingscentrum voor Land- en Tuinbouw (Beitem-Rumbeke) for research facilities. J. D. L. is indebted to the Instituut tot Aanmoediging van het Wetenschappelijk Onderzoek in Nijverheid en Landbouw (IWONL) and the Fonds voor Geneeskundig Wetenschappelijk Onderzoek (FGWO) for research and personnel grants. K.K., J.S. and M.Go. are indebted to the Nationaal Fonds voor Wetenschappelijk Onderzoek (NFWO).

\section{REFERENCES}

Bauer, A. W., Kirby, W. M. M., Sherris, J. C. \& TurCK, M. (1966). Antibiotic susceptibility testing by a standardized single disk method. American Journal of Clinical Pathology 45, 493-497.

Bonham-CarTer, G. F. (1967). Fortran IV Program for $Q$-mode Cluster Analysis of Nonquantitative Data Using IBM 7090/7094 Computers. Kansas Geological Survey Computer Program. Lawrence, USA: University of Kansas.

Cutri, S. S., Macauley, B. J. \& Roberts, W. P. (1984). Characteristics of pathogenic non-fluorescent (smooth) and non-pathogenic fluorescent (rough) forms of Pseudomonas tolaasii and Pseudomonas gingeri. Journal of Applied Bacteriology 57, 291-298.

De Ley, J., Cattoir, H. \& Reynaerts, A. (1970). The quantitative measurement of DNA hybridization from renaturation rates. European Journal of Biochemistry 12, 133-142.

DE Vos, P. \& DE LEY, J. (1983). Intra- and intergeneric similarities of Pseudomonas and Xanthomonas ribosomal ribonucleic acid cistrons. International Journal of Systematic Bacteriology 33, 487-509.

DE Vos, P., Goor, M., Gillis, M. \& De Ley, J. (1985). Ribosomal ribonucleic acid cistron similarities of phytopathogenic Pseudomonas species. International Journal of Systematic Bacteriology 35, 169-184.
DYE, D. W. (1968). A taxonomic study of the genus Erwinia. I. The 'amylovora' group. New Zealand Journal of Science 11, 590-607.

FAHY, P. C. (1981). The taxonomy of the bacterial plant pathogens of mushroom culture. Mushroom Science 11, 293-311.

Hugh, R. \& Leifson, E. (1953). The taxonomic significance of fermentative versus oxidative metabolism of carbohydrates by various Gramnegative bacteria. Journal of Bacteriology 66, 24-26.

KERSTERS, K. \& DE LEY, J. (1975). Identification and grouping of bacteria by numerical analysis of their electrophoretic protein patterns. Journal of General Microbiology 87, 333-342.

KING, E. O., WARD, W. K. \& RANeY, D. E. (1954). Two simple media for the demonstration of pyocyanin and fluorescein. Journal of Laboratory and Clinical Medicine 44, 301-307.

Kovács, N. (1956). Identification of Pseudomonas pyocyanea by the oxidase reaction. Nature, London 178, 703.

Lapage, S. P., Sneath, P. H. A., Lessel, E. F., Skerman, V. B. D., Seeliger, H. P. R. \& Clark, W. A. (editors) (1975). International Code of Nomenclature of Bacteria. Washington, DC: American Society for Microbiology. 
LAROCHE, M. \& VERHOYEN, M. (1981). Identification sérologique des phytobactéries en Belgique. Mededelingen van de Faculteit van de Landbouwwetenschappen, Rijksuniversiteit Gent 46/3, 757-771.

Lelliott, R. A., Billing, E. \& Hayward, A. C. (1966). A determinative scheme for the fluorescent plant pathogenic pseudomonads. Journal of Applied Bacteriology 29, 470-489.

MacFaddin, J. F. (1976). Biochemical Tests for Identification of Medical Bacteria. Baltimore: Williams \& Wilkins.

MARMUR, J. (1961). A procedure for the isolation of deoxyribonucleic acid from micro-organisms. Journal of Molecular Biology 3, 208-218.

Møller, V. (1955). Simplified test for some amino acid decarboxylases and for the arginine dihydrolase system. Acta pathologica et microbiologica scandinavica 36, 158-172.

Olivier, J. M., Guillaumes, J. \& Martin, D. (1978). Study of a bacterial disease of mushroom caps. Proceedings of the Fourth International Conference on Plant Pathogenic Bacteria, Angers, pp. 903-916.

Paine, S. G. (1919). Studies in bacteriosis. II. A brown blotch disease of cultivated mushrooms. Annals of Applied Biology 5, 206-219.

Palleroni, N. J. (1984). Genus I. Pseudomonas Migula 1894. In Bergey's Manual of Systematic Bacteriology, vol. 1, pp. 141-199. Edited by N. R. Krieg. Baltimore/London, Ontario: Williams \& Wilkins.

Preece, T. F. \& WONG, W. C. (1982). Quantitative and scanning electron microscope observations on the attachment of Pseudomonas tolaasii and other bacteria to the surface of Agaricus bisporus. Physiological Plant Pathology 21, 251-257.

SCHisler, L. C., Sinden, J. W. \& Sigel, E. M. (1968). Etiology of mummy disease of cultivated mushrooms. Phytopathology 58, 944-948.

SIERRA, G. (1957). A simple method for the detection of lipolytic activity of microorganisms and some observations on the influence of the contact between cells and fatty substrates. Antonie van Leeuwenhoek $23,15-22$.

Skerman, V. B. D., McGowan, V. \& Sneath, P. H. A. (1980). Approved Lists of Bacterial Names. International Journal of Systematic Bacteriology 30, 225-420.

SNEATH, P. H. A. (1956). Cultural and biochemical characteristics of the genus Chromobacterium. Journal of General Microbiology 15, 70-98.

SNEATH, P. H. A. \& SOKal, R. R. (1973). Numerical Taxonomy. The Principles and Practice of Numerical Classification. San Francisco: W. H. Freeman.

Stanier, R. Y., Palleroni, N. J. \& Doudoroff, M (1966). The aerobic pseudomonads: a taxonomic study. Journal of General Microbiology 43, 159-271.

TolaAs, A. G. (1915). A bacterial disease of cultivated mushrooms. Phytopathology 5, 51-54.

WishaRT, D. (1978). Clustan User Manual, 3rd edn. Interuniversity Research Councils Series, Report no. 47.

Wong, W. C. \& Preece, T. F. (1979). Identification of Pseudomonas tolaasii: the white line test in agar and mushroom tissue block rapid pitting tests. Journal of Applied Bacteriology 47, 401-407.

WONG, W. C., Fletcher, J. T., UnSworth, B. A. \& Preece, T. F. (1982). A note on ginger blotch, a new bacterial disease of the cultivated mushroom, Agaricus bisporus. Journal of Applied Bacteriology 52, 4348.

Young, J. M. (1970). Drippy gill - a bacterial disease of cultivated mushrooms caused by Pseudomonas agarici n. sp. New Zealand Journal of Agricultural Research 13, 977-990.

Zarkower, P. A., Wuest, P. J., RoYse, D. J. \& MYERS, B. (1984). Phenotypic traits of fluorescent pseudomonads causing bacterial blotch of Agaricus bisporus mushrooms and other mushroom-derived fluorescent pseudomonads. Canadian Journal of Microbiology 30, 360-367. 